\title{
Administering the Environment: Compliance Enforcement and Challenges
}

\author{
Kola O. Odeku \\ Faculty of Management and Law, University of Limpopo, Turfloop, South Africa
}

Doi:10.5901/mjss.2014.v5n23p2694

\begin{abstract}
The environment needs to be protected from various harmful substances and vices. In this regard, administrative law provides ample principles that can be used to administer and enforce environmental principles and laws. In the course of administration, the rules are to guide and fully complied with so as not to act ultra vires. All interested parties have to be given access and opportunity before any decision is made. This paper looks at how the environment can be managed and protected for the benefit of all and the necessary and just administrative actions that can be used against transgressors to remedy and restore the damage done.
\end{abstract}

Keywords: Environment, Protection, Harmful substance, Decisions, transgressors

\section{Introduction}

The right to clean and sustainable environment is well articulated in section 24 of the Constitution of the Federal Republic of South Africa, Act 108 of 1998 (Du Plessis, 2008). Pursuant to this, various policies have been put in place for the purposes of realisation and fulfilment of the right ( Murombo and Valentine, 2011). With regard to the administration and management of the environment, the government uses the National Environment Management Act (NEMA) Act 107 of 1998 and it explicitly providing for co-operative environmental governance by establishing principles for decision making on matters affecting the environment, institutions that will promote cooperative governance and procedures for cocoordinating environmental functions exercised by organs of the state to provide for certain aspects of the administration and enforcement of environmental management laws. Legislation depends on enforcement and implementation by the state for its effectiveness (Demmke and Deakin, 2001). In South Africa, a number of organs of state are responsible for the administration of environmental legislation and they are found in all sphere of government (Rossouw and Wiseman, 2004). It is pertinent to point out that when it comes to management and regulation of the environment, the departments of environmental affairs and tourism and water affairs and forestry are the main players. Therefore, the responsibility to administer and manage the environment begins from the national to provincial and the local authorities.

The major concern is that the responsibility to protect the environment has been placed in the hands of different organs with no particular centre that manages cohesion and synergy. This is creating ineffective administrative implementation and tensions amongst the departments. To this end, Rossouw and Wiseman (2004) point out that "whilst environmental policy and legislation embody sound democratic principles, implementation, compliance and enforcement are lagging. The lack of a strategic national framework for sustainable development confuses the responsibilities of national, provincial and local government. Established environmental assessment tools are compromised by conflicts over the integration of social, economic and environmental issues."

\section{Constitutional and Responsibility to Protect}

The Bill of Rights in the Constitution of South Africa is enviably supreme and protects the rights of everyone living in South Africa pursuant to section 7 of the constitution. Section 7(2) is the umbrella under which all protective rights are covered and respected. It mandates the various institutions, particularly the administrators, to make sure that these rights are enjoyed and fulfilled. It is therefore within place to assert that the Constitution envisages that the institutions and the administrators must, as a matter of fact and law, ensure that the environment is protected and enjoyed. The right to clean and sustainable environment also enjoys the protective mechanisms from all aspects of the organs of government like the legislature, the executive, the judiciary and all organs of state including the fourth realm of the estate-the media (Kotzé, 2007). As aptly points out by Kotzé (2007) that "the 1996 Constitution of the Republic of South Africa explicitly provides for a comprehensive environmental right. The environmental right is part of the supreme law of the country and the entire 
environmental law regime. South Africa also has a vigilant judiciary, which has had various opportunities to interpret and give meaning to the environmental right." Protection of the environment therefore calls for a collective responsibility that runs through the rank and files (Blackburn, 2012).

\section{Protective Mechanisms}

The administrative power to protect and fulfil environmental right is derived from the statutes and policy such that the administrator can exercise the power without fear or favour. The statues are clear on the mandate and power of the administrator in order for it not to act ultras vires. Therefore, the implementation and administration of environmental laws can be well discharged by relying on the legislation. In the case of The MEC for Agriculture, Conservation, Environment and Land Affairs v Sasol oil (pty) Itd and another 2006 (2) ALL SA 17 SCA, the court observed thus "the interpretation of environmental law must be consistent with the purpose of the law, the environmental rights set out in the constitution and other relevant statutory provisions that are part of the environmental laws. The national environmental management act says that the interpretation of any concerned with protecting and managing the environment must be guided by its principles. At the heart of NEMA principles it is the principle of sustainable development, this means that organs of state must evaluate the social, economic, and environmental impacts of activities that may significantly affect the environment" The court supported the argument canvassed by the Department and held that the guidelines and the law they applied were correct and as such, they acted within the ambit of the law in protecting the environment (Fuggie and Rabie, 1992).

\section{Discharging the Environmental Management Mandates and Plans}

Proper environmental management and plans need to be in line with Section 24 of National environment management act 107 of 1998 ( NEMA), which deals with the implementation of the general objectives of integrated environmental management and provides that: in order to give effect to the general objectives of integrated environmental management laid down in chapter 5 of NEMA, activities which may significantly have a potential impact on; the environment, socioeconomic conditions, and, the cultural heritage, must be considered, investigated and assessed prior to their implementation and reported to the organ of state charged by law with authorizing, permitting, or otherwise allowing the implementation of an activity.

Section 23 of NEMA sets out these general objectives. These include the objectives to promote the integration of the national environmental management principles into decisions that may significantly affect the environment, and to identify, predict and evaluate actual and potential impact on the environment, socio-economic conditions and cultural heritage (Kihato, 2013). Their apparent purpose is to minimize the negative impact on the environment and socioeconomic conditions and to promote compliance with the principles of environmental management (Faasen, 2014). Section 22 (1) of Environmental conservation act 63 OF 1989 (ECA) provides that actions which may significantly affect the environment must be considered, investigated and assessed prior to their implementation and reported upon to the organ of state charged by law with authorising the implementation of an activity. To underscore the importance of this requirement, subsection 24(7) requires that any investigation must, as a minimum investigate the potential impact, including the cumulative effects of the proposed development on the environment, socio-economic conditions and cultural heritage.

Environmental Management Plan (EMP) is a document that provides a description of methods and procedures for mitigating and monitoring impacts (Ridgway, 2005). The EMP also provides for environmental objectives and targets which the developer needs to achieve in order to reduce negative impacts on the environment. The objectives of EMP are to:

a. Identify the possible environmental impacts of the proposed activity and

b. Development measures to minimize mitigate and manage the impacts.

The overall objective is therefore to ensure and assure that whatever will harm the environment during project handling and commissioning is mitigated and prevented from the onset "the EMP also serves to highlight specific requirements that will be monitored during the development and should the environmental impacts not have been satisfactory prevented or mitigated, corrective action will have to be taken. The document should, therefore, be seen as a guideline that will assist in minimising the potential environmental impact of activities."

\section{Managing and Administering the Environment}

In South Africa, the National Environmental advisory forum is tasked with the responsibility of informing the Minister for 
Environment of the views of stakeholders regarding the application of the principles of NEMA in Section 2 and advice the minister on any matter concerning environmental management, governance and specifically, the setting and achievement of objectives and priorities for environmental governance, and appropriate methods of monitoring compliance with the principles of NEMA. The forum may, on its own initiative and after consultation with the Director General, draw the minister's attention to any matter concerning environmental management requiring attention and the minister may refer matter for consideration by the forum.

The objectives of the Committee for Environmental coordination is to promote integration and coordination of environmental functions by the relevant organs of the state and to promote the achievement of the purpose objectives of environmental implementation plans and environmental management plans in terms of Section 12 of NEMA.

\section{Management and Administrative Challenges}

There are many challenges being faced by the institutions responsible for the management and administration of the environment and these are having a huge impact on the delivery and maintaining of clean and benign environment (Blackburn, 2012).

The lack of policing due mainly to lack of resources to monitor environmental compliance and enforcement is an issue (Schmidt, 2004). The administration of a number of South African environmental responsibilities has been assigned to provinces that are already burdened with budget deficits and unable to cater for a large number of pressing socioeconomics goods and services to the people.

Inadequate information dissemination creating low public awareness is also a major challenge and threat to the environment. Minority that are aware of the issues concerning the environment have lackadaisical attitudes and as such they do not care about assisting in the dissemination of environmental information or report environmental wrong doings and offences. There are inadequacy and inefficiency in the investigations of contravention of environmental law due to capacity gap, hence perpetrators are not brought to book.

Specialist and technical expertise required for effective environmental investigations and litigations are scarce because most officials do not have the required skills. However, it is important to point out that this skill gap can easily be solved through ample training. The problem tied to this solution is that there are inadequate resources to implement ample training.

Undoubtedly, environmental pollution continues to thrive due mainly to lack of expertise in the prosecution of environmental offences in South Africa (White, 2013). This problem is linked to inadequate penalties in the statutes to deter perpetrators (Watson, 2005). While civil liability of the offender will provide some sorts of remedies to the damaged done, criminal responsibility should also be imposed as an additional penalty for the purposes of deterrent to future would-be environmental offenders and the society at large that any injury inflicted to the environment will be severely sanctioned and punished (Adler and Lord, 1990).

\section{Administering and Enforcing Environmental Laws}

Administrative law is the body of law that governs the activities of administrative agencies of government which can be discharged by specifically administering the law either for regulatory or enforcement purposes (Freeman, 2000). With regard to the administration of the environment, specific principles of administrative law including but not limited to administration, adjudication, compliance, monitoring, and enforcement and so on are incorporated. (Cane, 2011).

Environmental law forms part of the principles of administrative law since the principles of administrative law apply to all environmental issues, unless expressly excluded by statute (Stewart, 1976). Environmental law consist of provisions which either directly impose obligations or prohibitions upon individuals or which entrust the care of natural resources and the control of pollution to administrative bodies ( Quick and Pistorius, 1994). Successful implementation of any environmental law depends upon whether the exercise of such power furthers the public interest in environmental conservation and ensures that the environment is kept safe from harmful substances (Lazarus, 2008). Similarly, the success of environmental law depends upon the efficiency and efficacy of administrative bodies (Cole and Grossman, 1999). Environmental law as part of administrative law falls within the ambit of public law (Stewart, 2003). The relationship is characterized by the fact that one of the parties to the relationship is always an organ of the state and the individual (Raustiala, 1997). The task of the state administrator is the implementation of environmental legislation which is promulgated by the national, provincial and local spheres of government. Section 33 of the constitution guarantees the right to just administrative action, which requires that all administrative action must be lawful, reasonable and procedurally fair and that written reasons must be provided for administrative decisions. 
In the case of The Director, mineral development Gauteng region and SASOL mining (PTY) LTD v Save the Vaal environment and others 1999 (2) ALL SA 38 (A), the supreme court of appeal considered the right to participate in an environmental decision-making process. The people concerned were mainly property owners whose environment was the subject of an environmental decision-making process. The court decided that:

1. Before permit is given to authorising mining activities, government must be prepared to listen to the views of the people who might be affected by the potential environmental impacts.

2. Interested and affected parties must be told about the application for a new mining activity and given a chance to raise their objections in writing. If it is necessary, after the submission of written objections, a more formal hearing can take place.

3. The kinds of environmental concerns that can be raised include destruction of plants and animals, pollution, loss of jobs and small businesses and the depreciation of property values as a result of mining.

The decision of the court shows that all interested parties to the matter must be amply informed of all the processes from the beginning to the end and that no one should be deprived or denied any information that could be used to make an informed decision.

However, the court will not assist anyone who tries to be malicious in its claim for the purposes of adjudication especially, where the fact in issue has been successfully dealt with by the competent body. This was the decision of the court in the case of Wildlife and Environment Society of South Africa v MEC for Economic Affairs, Environment and Tourism, Eastern cape Provincial 2005 (3) all SA 389 (E) where the court found that the appellant did not exercise due care and that it should have been aware that its concerns had already been addressed therefore the application was unnecessary.

The predominant command, control and compelling mechanisms for enforcement are the punitive and deterrent criminal sanction (Macrory, 2008). There are two aspects of this. Firstly, the penalty provided by the legislation and secondly, the penalty actually imposed by the courts. An important addition to environmental enforcement has been the use of directives such as section 31A of the Environment Conservation Act 73 of 1989 (ECA), section 19 of the National Water Act 36 of 1998 (NWA), section 45 of the Mineral and Petroleum Resources Development Act 28 of 2002 (MPRDA) and section 28 of the National Environmental Management Act 107 of 1998 (NEMA). These directives establish a duty of care and empower competent authorities to direct transgressors to take steps to remedy harm done to environment.

The essence of the above directives and their provisions in different Acts is to give opportunity to the transgressor to correct mistake made by righting the wrong. This measure is applicable in achieving restoration without necessarily imposing any sanction. This measure, to some extent will also impact on the transgressor financially as resources will be needed to remedy the situation.

\section{Ensuring Appropriate and Adequate Administrative Oversights}

Administration is an issue in environmental law and as such there is need to ensure that those who are interacting with the environment for their livelihoods need to be adequately enlightened on how best they can act or perform without contravening the regulations (Deshmukh, 2011). Allowing damages to be done to the environment will not serve the interest of the environment and the perpetrators hence, the need for information dissemination that will be useful to them to take necessary steps to take the right decision by acting responsibly (Mushal, 2007).

The administrator should provide ample access to environmental information for all; because this will be of help to make the right decision about what to do before taking an action. If the right decision is made, there will be no violation of the regulations and as such no consequences. Money ordinarily that will be spent on damages or restoration will be saved.

The constitution allows unhindered access to government and government agency's information. The Promotion of Access to Information Act Act 2 of 2000 (PAIA) promotes an unhindered access to information for purposes of knowing what is right and what is wrong. With regard to ample access to information that will be of benefits, NEMA and PAIA are closely linked. For example, while NEMA talks about information on pollution and waste products from industry which can never be private information but public, under PAIA, a person cannot refuse to give information unless it would harm the polluter's commercial interests (Brits et al. 2014). In the case of The Trustees for the Time Being of the biowatch Trust $v$ The Registrar: Genetic Resources and others, 200910 BCLR 1014 (CC) the court notably pronounced that "where a person has established a clear right of access to information, a failure to grant access is a continued infringement of a constitutional right."

In the case of Earthlife Africa (Cape Town) v Director General: Department of Environmental Affairs and Tourism an another 2005 (3) SA 156 (C) the court indicted that an interested party in any environmental issue that requires a 
certain decision to be taken ask the right to intervene before such decision is taken and it has been taken, such decision can be taken up for a judicial review.

\subsection{Public participation in environmental decision-making}

Involvement of the public in environmental decision-making will give all stake holders ample opportunity to express their views (Stern and Dietz, 2008). This will be of aid in making good decisions for environmental protection unlike decision taken that did not incorporate the views of others. The Constitution supports collective deliberations before a decision is taken and if not properly done, there is a right to just administrative action. Just administrative action means that the concerns of the public must be heard and listened to before giving permission for an activity that may significantly affect the environment (Denhardt et, 2013). This principle is set out in NEMA. The Promotion of Administrative Justice Act Act 3 of 2000 (PAJA) stipulates what the constitutional right to just administrative action means. It says that administrative action that may negatively affect your rights must follow fair procedures. Government has the discretion to decide if a public enquiry should be held in cases where administrative action negatively affects rights. It can also give a chance to make written comments if it decides that this is appropriate.

One of the ways that the public can participate in environmental decision-making is when an environmental impact assessment is about to be done before a new development commences (O'Faircheallaigh, 2010). The EIA must look at all the different ways in which the development can be done and choose the one that does the least harm to the environment (Therivel, 2010). It must also evaluate the impact of new developments on the socio-economic conditions of people and their cultural interests (Fuggie and Rabie 1992).

\subsection{Access to justice in promoting environmental right}

The first step to be taken in order to protect the environment is by soft remedial options and measures (Schädler et al. 2012). If this fails, the way to compel the protection of the environment and well-being is to approach a court for an order to restrain and institute actions against the transgressor (Daly and May, 2012). What have been the main challenges to instituting actions against transgressors is the fear of losing the case which will result in the plaintiff to pay the legal cost of the defendant (Hodges, 2006). Even if the case is won by the plaintiff, a lot of financial resource must have been expended. The financial burden is now lessen because the advent of NEMA has provided a window of opportunities for making complaints about damage to the environment to the government (Dalal-Clayton and Bass, 2009).

More importantly, alternative dispute resolution such as conciliation, facilitation and arbitration where there is any dispute on environmental issues could be explored. This has enormous benefits to all the parties concerns because it is less expensive, more effective and efficient than to right the wrong done to the environment (Cheldelin, 2003).

Access to information, public participation and access to justice are powerful important tools for exercising environmental rights ( Mitchell and Walker, 2007). The important thing is to use them effectively and efficiently in order to get the desired result.

NEMA is a powerful tool that assists to unpack our constitutional rights to safe and clean environment without having to know all the environmental laws. It has a set of principles that must be followed whenever government takes any action significantly affecting the environment. It also says that, whenever anybody 'significantly pollutes or degrades the environment' you can go to government to ask it to investigate and enforce the polluter to clean the pollution.

\section{Conclusion}

There must be proper and effective environmental administration. This can only be achieved if there are well-developed and effective plan that ensure that rules and regulations governing the environment are in place and observed at all times. Planning will result to good administration where access to ample information is given to the users of the environment. Invariably, this will contribute to the environmental awareness and users can make decisions that will not be harmful to the environment. Ample access to environmental plan and information also facilitate the prevention of environmental degradation and minimizes impacts when they are unavoidable.

As part of an effective administration, compliance and monitoring are crucial to achieving a benign environment. While constant information on how to use the environment sustainably should be part of the measures to keep the users informed of the various rules and regulations on the environment, appropriate civil and criminal actions should be taken against any transgressor. However, if there are provisions for alternative dispute resolution, administratively, it is advised that they should be explored. 


\section{References}

Adler R W, Lord C 1990. Environmental Crimes: Raising the Stakes. George Washington Law Review, 59:781-790.

Blackburn WR 2012. The Sustainability Handbook: The Complete Management Guide to Achieving Social, Economic and Environmental Responsibility. Earthscan, London, UK.

Blackburn WR 2012. The Sustainability Handbook:" The Complete Management Guide to Achieving Social, Economic and Environmental Responsibility. From http://books.google.co.za/books?hl=en\&lr=\&id=xccpthv- \&ots=9hvf_d jdg\&sig=yr-qwxtskjzxsqjdfog8tca1_y\#v=onepage\&q\&f=false. (Retrieved 27 July, 2014).

Cane P2011. Administrative law. Oxford University Press, Oxford, UK.

Cheldelin S 2003. Mediation and arbitration. YHT Ltd, London, UK.

Cole D H, Grossman P Z 1999. When is Command-and-Control Efficient - Institutions, Technology, and the Comparative Efficiency of Alternative Regulatory Regimes for Environmental Protection. Wisconsin Law Review, 1999:887-894.

Dalal-Clayton DB, Bass S 2009. The challenges of environmental mainstreaming: experience of integrating environment into development institutions and decisions. International Institute of Environmental and Development Publications, London, UK.

Daly E, May J 2012. Constitutional Environmental Rights and Liabilities. From http://papers.ssrn.com/sol3/papers.cfm ?abstract_id=2221561. (Retrieved 21 March, 2014).

Demmke C, Deakin SF 2001. Towards effective environmental regulation: innovative approaches in implementing and enforcing European environmental law and policy. Jean Monnet Progrmme. New York University, USA.

Denhardt R, Denhardt J, Blanc T 2013. Public administration: An action orientation. Wadsworth Cengage Learning, Boston, USA.

Deshmukh N 2011. Challenges before the Government Institutions in Environment Protection for Sustainable Development: Prescription and Practices in the Indian context. From http://neelimadeshmukh.org/pdf\%20convert/Complete\%20paper\%20for \%20IASIA\%20conf.30th\%20April2011.docx\%20\%20neelima.pdf. (Retrieved 2 March, 2014).

Du Plessis A 2008. Fulfilment of South Africa's Constitutional Environmental Right in the Local Government Sphere. From http://dspace.nwu.ac.za/handle/10394/2882. (Retrieved 14 Apri, 2014).

Faasen P 2014. An Assessment of Accommodation Strategies for Coastal Adaptation in Cape Town, South Africa, in Response to Climate Change. http://scholar.sun.ac.za/handle/10019.1/86665. (Retrieved 17 July, 2014).

Freeman J 2000. Private parties, public functions and the new administrative law, Administrative Law Review. 52(3): 813-858.

Fuggie RF, Rabie MA 1992. Environmental management in South Africa. Juta \& Co Ltd, Cape Town, South Africa.

Hodges C 2006. Competition enforcement, regulation and civil justice: what is the case? fromhttp://www.kluwerlawonline.com labstract.php?id=cola2006094\&phpsessid=m1celei7m73sfr11hg4j.jpuj56. (Retrieved 26 May, 2014).

Kihato M 2013. Integrating planning and environmental issues through the law in South Africa: learning from international experience. From http://uir.unisa.ac.za/handle/10500/8612. (Retrieved 17 July, 2014).

Kotzé LJ 2007. The Judiciary, the Environmental Right and the Quest for Sustainability in South Africa: A Critical Reflection. Review of European Community \& International Environmental Law. 16(3): 298-311.

Lazarus RJ 2008. The making of environmental law. http://books.google.co.za/books?hl=en\&lr=\&id=qqplzpswzqsc\&oi=fnd\&pg=pr7 \&dq=successful+ oseiwiibfnkwcudt53nm7lcawik\#v=onepage\&q\&f=false. (Retrieved 27 July, 2014).

Macrory R 2008. Regulation, Enforcement and Governance of Environmental Law. Cameron May Ltd, London, UK.

Mitchell G, Walker G 2007. Methodological issues in the assessment of environmental equity and environmental justice. Routledge, New York, USA.

Murombo T, Valentine H 2011. SLAPP suits: an emerging obstacle to public interest environmental litigation in South Africa. South African Journal on Human Rights, 27(1): 82-106.

Mushal RW 2007. Reflections upon American Environmental Enforcement Experience as it may Relate to Post-Hampton Developments in England and Wales. Journal of environmental law, 19 (2): 201-226.

N Brits, W Meyer, RB Hayes - 2014. Draft scoping report under NEMA, 1998. From sahra.org.za. (Retrieved 23 September, 2014).

O'Faircheallaigh C 2010. Public participation and environmental impact assessment: Purposes, implications, and lessons for public policy making. Environmental Impact Assessment Review, 30(1):19-27.

Quick A J R, . Pistorius PA 1994. Environmental issues and management strategies in Metropolitan Cape Town. Urban Forum, 5(2): 4568.

Raustiala K 1997. Participatory Revolution in International Environmental Law. 21 Harvard Environmental Law Review, 21:537-545.

Ridgway B 2005. Environmental management system provides tools for delivering on environmental impact assessment commitments. Impact Assessment and Project Appraisal. 23(4): 325-331.

Rossouw N, Wiseman K 2004. Learning from the implementation of environmental public policy instruments after the first ten years of democracy in South Africa. Impact Assessment and Project Appraisal, 22(2): 131-140.

Schädler S, Morio M, Bartke S, Finkel M 2012. ' Integrated planning and spatial evaluation of megasite remediation and reuse options. Journal of Contaminant Hydrology. 127( 1-4): 88-100.

Schmidt CW 2004. Environmental crimes: profiting at earth's expense. Environmental Health Perspectives, 112(2):a96-103.

Stern PC, Dietz T 2008. Public participation in environmental assessment and decision making.Fromhttp://books.google.co.za /books?hl=en\&lr=\&id=j3adagaaqbaj\&oi=fnd\&pg=pt17\&dq= 3ud9ufthrivxsfgall2cxwxtjto\#v=onepage\&q\&f=false. (Retrieved 21 February, 2014).

Stewart, Richard B 2003. Administrative Law in the Twenty-First Century. New York University Law Review, 78: 437-445. 
Stewart, Richard B. 1976. Development of Administrative and Quasi-Constitutional Law in Judicial Review of Environmental Decisionmaking: Lessons from the Clean Air Act. lowa LawReview,62:713-721.

Therivel R 2010. Strategic environmental assessment in action. Earthscan, London, UK.

Watson M 2005. Environmental Offences: the Reality of Environmental Crime. Environmental Law Review, 7(3): 190-200.

White R 2013. Environmental harm: An eco-justice perspective. Policy Press, Bristol, UK. 